\title{
On imperfect competition and market distortions: The causes of corporate under-investment in energy and material efficiency
}

\author{
Jun Rentschler1) 2)*, Raimund Bleischwitz ${ }^{1)}$, Florian Flachenecker ${ }^{1)}$ \\ ${ }^{1)}$ University College London, London, UK \\ ${ }^{2)}$ Oxford Institute for Energy Studies, Oxford, UK
}

\begin{abstract}
In practice firms are faced by a range of market frictions and barriers, which prevent them from undertaking investments in efficiency and low-carbon technologies. Thus, even when environmental taxes are imposed, firms may be unable (or unwilling) to adjust their behaviour and technology in response to price signals. With a focus on energy and material efficiency investments, this paper systematically investigates how the theoretical assumptions of perfectly competitive and efficient markets are violated in practice, and how this results in complex and interlinked investment barriers. It classifies five categories of investment barriers: information, capacity, and financial constraints, as well as uncompetitive market structures and fiscal mismanagement; and presents evidence on each of these. It concludes by proposing a range of measures for mitigating investment barriers, and addressing their structural causes. Overall, the evidence presented in this paper aims to help increase the effectiveness of environmental taxes and regulation, by identifying market imperfections that environmental taxes alone cannot address.
\end{abstract}

Key words: Investment barriers; Efficiency; Firms; Environmental taxes

JEL codes: H23, H32, L22

\footnotetext{
* Corresponding author: jun.rentschler.10@ucl.ac.uk, University College London, Institute for Sustainable Resources, Central House, 14 Upper Woburn Place, London WC1H 0NN
} 


\section{Introduction}

\subsection{Externality taxes in the presence of market distortions}

Overconsumption of energy and resources, as well as their inefficient use are a key source of negative externalities, such as carbon emissions, pollution and the associated impacts on health. Pigou (1920) proposed to impose a tax on those activities that cause negative externalities, and argued that a tax which corresponds to the external social cost of certain activities will change behaviours and maximise social welfare (Aldy et al., 2010). The introduction of carbon taxes, fuel taxes, pollution taxes, congestion charges, or waste tariffs all follow the Pigouvian principle and will result in higher factor prices and production costs particularly for resource and energy intensive firms. Also the removal of subsidies for fossil fuels or inefficient industries are Pigouvian in the sense that they internalise social and environmental costs to some (albeit not full) extent.

In an ideal setting, environmental taxation is the most efficient way of incentivising firms to increase factor productivity, i.e. improving energy efficiency, lowering resource use, and reducing carbon emissions, by modernising production processes and infrastructure, and investing in other efficiency enhancing measures (Requate, 1998). In short, firms are expected to implement exactly those measures, which reduce social costs and environmental impacts. In addition, there is evidence for a double dividend from externality taxes, as tax revenues can be used to reduce other distortionary taxes (e.g. on labour) and mitigate associated economic inefficiencies (Bovenberg, 1999; Goulder, 2013). In theory, this makes externality taxes preferable to command \& control instruments (such as efficiency standards) - and yet the political challenges of raising externality taxes have meant that energy or fuel efficiency standards (or even inaction) remain attractive alternatives (Parry et al., 2014).

Indeed, in practice Pigouvian taxes can be unpopular and ineffective without complementary policies. For instance, in an urban setting, Avner et al. (2014) show that the effectiveness of carbon and fuel taxes is significantly lower, when they are not complemented by investments in public transport infrastructure. In practice it is also challenging to estimate the adequate level of a Pigouvian tax (e.g. Pindyck, 2013, on the social cost of carbon), and knowledge spillovers, imperfect foresight and lacking credibility of a long-term carbon price can undermine effectiveness (Acemoglu et al., 2012; Hallegatte et al., 2013; Vogt-Schilb \& Hallegatte, 2014). Moreover, the negative impact on existing polluting capital and stranded assets come at political costs, which hamper implementation (Rozenberg et al., 2014).

This paper argues that at the firm level the effectiveness of environmental taxes, and green fiscal reforms (e.g. fuel subsidies removal), depends crucially on whether and how firms are able to respond to changing price incentives (e.g. by increasing energy and resource efficiency). In fact, for modernising production processes and realising efficiency gains, firms rely on a wide range of factors such as access to technology and information, technical capacity, and financial infrastructure. The absence of any of these factors, as well as constrained competition, trade protectionism, and fiscal mismanagement are likely to create barriers for firms to respond to environmental taxes by increasing energy and resource efficiency. These barriers can prevent the "first-best outcomes" of environmental taxes to be achieved, and have been often overlooked in the literature on environmental policy and clean investments (Requate, 2003; 2004; Domenech et al., 2014; Dijk \& Kemp, 2016).

This paper shows that these barriers form a complex web, which obstructs corporate investments in efficiency, and hence diminishes the effectiveness of "green price instruments". The complexity and interconnectedness of these barriers is difficult to capture in theoretical analyses on the effectiveness of externality taxes. Some General Equilibrium models account 
for pre-existing distortionary taxes, or for imperfect information when analysing the impacts of carbon taxes (Parry et al., 1999; Bovenberg \& Goulder, 1996) - however, they typically yield an incomplete account of challenges in the wider political economy and investment environment. In fact, theoretical studies of policy optimality tend to be based on the assumption of perfect competition, while far fewer studies consider the real need for second-best policy solutions (Montero, 2002; Lipsey \& Lancaster, 1956).

This paper systematically reviews the barriers which may prevent firms from responding to the incentives set through environmental pricing instruments (including pollution taxes, or environmental regulation). As a benchmark, this paper refers to the fundamental theorems of welfare economics and the hypothetical characteristics of perfectly competitive markets (Section 1.2). It analyses how the hypothetical conditions which underlie perfectly competitive markets are violated in practice due to market failures and distortions, thus preventing firms from improving efficiency (Section 2). It argues that these distortions create investment barriers, which are exacerbated by systemic risks and uncertainty. It concludes that environmental taxes and subsidy reforms are likely to be ineffective without complementary policies which mitigate market distortions (Section 3).

\subsection{Competitive markets, distortions and the rationale for complementary policies}

Barriers and market distortions can diminish the effectiveness of Pigouvian taxes, as they prevent firms from improving material or energy efficiency in response to price signals (Flachenecker \& Rentschler, 2015). In order to understand and categorise these barriers this paper refers to the two Fundamental Theorems of Welfare Economics: The First Fundamental Welfare Theorem suggests perfectly competitive markets as a hypothetical benchmark for investigating the efficiency of actual market outcomes. Such perfectly competitive markets are based on several assumptions, including (Blaug, 2007):

- Perfect information

- No oligo- or monopolies

- No barriers to market entry (or exit)

- Perfect factor mobility

- Zero transaction costs

- Absence of externalities.

The violation of any of these assumptions leads to market failures, which hamper the effectiveness of externality taxes.

Also in the context of firms' energy and resource efficiency, violations of these assumptions are ubiquitous in practice: Information or capacity constraints can lead to inefficient decision making in the face of environmental taxes. Missing or inefficient markets (e.g. for credit) can constrain the implementation of efficiency enhancing measures. Other missing markets (e.g. for carbon) can lead to severe externalities and excess waste. Large firms and protected industries face little competitive pressures to invest in efficiency gains, especially if protectionist trade policies are in place. This may also mean that environmental taxes are simply passed on to consumers, while firms take no further efficiency enhancing measures. Physical production infrastructure tends to be difficult and expensive to adjust to frequently changing market conditions, leading to long-term technology lock-in. Overall, all such factors will limit the ability of firms to respond to price based environmental policies (e.g. taxes and subsidy reforms) by improving energy or resource efficiency. 
If no additional measures are undertaken to alleviate these barriers, firms may have few means to reduce the environmental tax burden. This will possibly reduce firms' competitiveness while the actual policy objective of reducing environmental externalities remains unaccomplished. Moreover, without complementary measures to reduce investment barriers, the accumulation of new productive capital is likely to be characterised by inefficiency. This infrastructure then pre-determines and possibly restricts investment and innovation options available in the future. Such so called 'path dependence' can even result in a lock-in situation, in which costs associated with pre-existing inefficiency prevent any future investments into efficiency and green innovation (Hallegatte et al., 2013).

In practice, the assumptions underlying perfectly competitive markets are violated in many ways; not rarely due to inadequate policy making and regulation. However on the flipside, the Second Welfare Theorem assigns an important role to market interventions (e.g. by governments), stating that they may improve Pareto efficiency of a given economic allocation by redistributing resources. In practice however, the government's role can also be negative if public policy provides perverse incentives (e.g. by subsidising inefficient behaviour), thus perpetuating inefficiencies. Within this framing, the subsequent sections will discuss specific barriers which may prevent firms from implementing energy and resource efficiency, and green innovation measures. It will thus suggest entry points for measures to complement standard price based environmental policies.

\section{Barriers to resource efficiency investments}

Ideally, environmental taxes and removal of distortive subsidies (e.g. fossil fuel subsidies) will increase the cost of polluting production practices, and thus cause firms to invest into cleaner, more efficient, low-carbon technology. However in practice, barriers may mean that investments do not deliver the anticipated efficiency gains, or that they are not undertaken at all. Based on Flachenecker \& Rentschler (2015), this chapter outlines the key barriers as summarised in Table 1, and presents a framework for systematically assessing the environment within which efficiency investments take place. Each of the columns corresponds to a violation of one (or more) of the basic hypothetical conditions for perfectly competitive and efficient markets. This extends the discussion on market failures by Gillingham et al. (2009) by providing empirical evidence at the firm level.

\begin{tabular}{|c|c|c|c|c|c|}
\hline \multicolumn{6}{|c|}{ Barriers to Investments in Energy \& Resource Efficiency } \\
\hline $\begin{array}{c}\text { Investment } \\
\text { barriers at } \\
\text { the firm or } \\
\text { government } \\
\text { level }\end{array}$ & $\begin{array}{l}\text { Information } \\
\text { constraints } \\
\text { - Limited } \\
\text { information } \\
\text { on scale and } \\
\text { type of } \\
\text { inefficiencies } \\
\text { (monitoring \& } \\
\text { disclosure) } \\
\text { - Limited } \\
\text { information on } \\
\text { modern } \\
\text { technology and } \\
\text { methods } \\
\text { (access \& } \\
\text { dissemination) }\end{array}$ & \begin{tabular}{l}
\multicolumn{1}{c}{ Capacity } \\
constraints \\
- Technical \\
capacity \\
- Managerial \\
capacity \\
- Institutional \\
capacity \\
- Lacking \\
awareness \& \\
individual \\
biases
\end{tabular} & $\begin{array}{l}\text { Financial } \\
\text { constraints } \\
\text { - Uncertain } \\
\text { payoffs } \\
\text { hamper } \\
\text { financing (e.g. } \\
\text { due to lacking } \\
\text { information) } \\
\text { - Competing } \\
\text { investment } \\
\text { opportunities } \\
\text { - Inadequate } \\
\text { credit markets }\end{array}$ & \begin{tabular}{|l}
\multicolumn{1}{c}{ Market } \\
structures \\
- Lack of \\
competition \\
(e.g. mono-/ \\
oligopolies) \\
- Protected \\
industries \\
- Trade \\
protectionism
\end{tabular} & \begin{tabular}{l}
\multicolumn{1}{c}{ Fiscal mis- } \\
management \\
- Subsidies to \\
inefficient, \\
polluting \\
industries \\
- Subsidies for \\
polluting \\
inputs (e.g. \\
fossil fuels) \\
- Lacking \\
enforcement \\
(e.g. carbon \\
taxes \& \\
landfill tariffs)
\end{tabular} \\
\hline
\end{tabular}




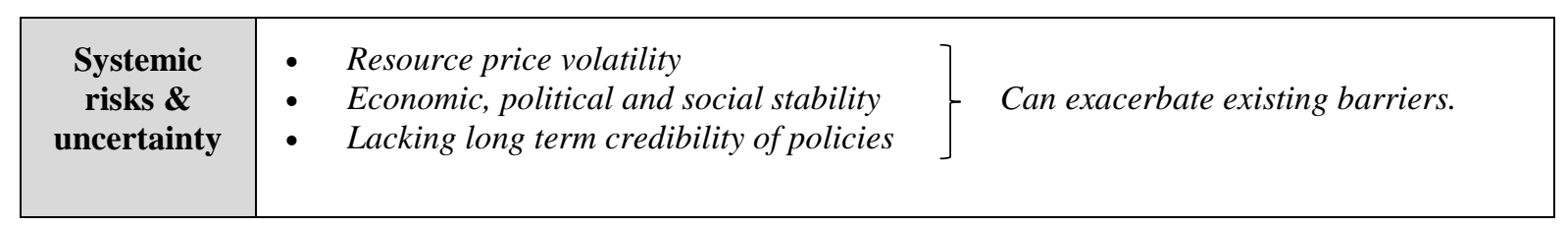

Table 1. Barriers to efficiency investments: Underinvestment in energy \& resource efficiency can be due to various market or government failures (Flachenecker \& Rentschler, 2015). ${ }^{1}$

\subsection{Information constraints}

\section{Monitoring \& disclosure: limited information on the scale and nature of inefficiencies}

'Imperfect' information violates one of the key assumptions underlying efficient markets. Which are the most inefficient processes in a specific firm (or industry)? How inefficient are they? Without this knowledge firms may be unable to undertake targeted investments in response to environmental taxes, and governments may be unable to design adequately targeted policies to complement environmental taxes. Specifically, there are two major issues: (i) Insufficient firm level monitoring of energy and resource efficiency and environmental performance (possibly due to insufficient legal disclosure requirements): This may prevent firms from identifying whether and where within their operations green investments can reduce environmental tax burdens; and (ii) insufficient information disclosure of environmental performance and lacking industry level monitoring of efficiency: This may prevent governments from designing targeted policies to complement environmental taxes.

The lack of comprehensive, regular monitoring and disclosure at the firm and household level makes it difficult to track potential improvements, and identify particularly successful investments. The Principles of Corporate Governance by the Organisation for Economic Cooperation and Development (OECD, 2004) argue that an effective legal framework is critical for ensuring an industry wide practice of information disclosure. When enforced effectively, this will entail better performance monitoring at the firm level, thus facilitating efficiency enhancing investments and modernisation measures (OECD, 2004; World Bank, 2006). Furthermore, Onischka et al. (2012) argue that reporting requirements on corporate resource and energy efficiency performance and investments are critical for increasing the acceptance by firms (and banks) of resource efficiency projects. They also suggest that in the longer term such disclosure practices can play an important role in making commercial financing of energy and resource efficiency more accessible and affordable.

The introduction of environmental taxes and regulation may put the access to and affordability of vital inputs at risk. In order to mitigate the risks from input scarcity, firms will need to improve the efficiency with which such inputs are used. However, the monitoring and disclosure of such resource input related risks remain limited. A series of assessments has shown that e.g. in the Eastern Europe, Central Asia, Middle East, and North Africa, disclosure of corporate information (e.g. on technological or environmental risks to operations) remains insufficient in terms of coverage and quality (World Bank, 2006; 2004; 2004). In a model of technology adoption and policy timing, D'Amato \& Dijkstra (2015) show that resulting information asymmetries can result in corporate under-investment in efficient technology.

If implemented comprehensively, the benefits of performance monitoring and disclosure can mitigate information constraints at the macro level: As policy makers gain a better understanding of inefficiencies in the energy and resource use of the private sector, they are able to design targeted measures and regulation for complementing Pigouvian taxes. In the

\footnotetext{
${ }^{1}$ This categorisation of barriers is adapted from Chapter 2 of the World Bank's World Development Report 2014 (Typology of obstacles to risk management) by Stéphane Hallegatte.
} 
European Union (EU) for instance, firm level surveys have managed to identify the key barriers, which prevent firms from improving their resource and energy efficiency (European Commission, 2013). The "Roadmap to a Resource Efficient Europe" (European Commission, 2011) and the EU Energy Efficiency Directive (European Commission, 2012), which outline goals and policy measures for increasing efficiency at a large scale, critically rely on such information. This confirms studies by Baron (1985) and Laffont (1994) who highlight the important role of information for designing effective environmental policy.

\section{Dissemination, access and management: limited information on the solutions}

Firms are necessarily unable to implement low-carbon, less polluting technology, when markets (or governments) fail to provide adequate information on the costs, benefits, and methods of increasing the efficiency of resource and energy use in their production processes. The Asian Development Bank (ADB, 2013) notes that the lack of information considerably increases the transaction costs (in terms of time and effort) of implementing energy and resource efficiency measures, as well as of modernisation and green innovation more generally. Evidence for SMEs in China shows that information constraints are one of the key barriers to energy efficiency investments (Kostka et al., 2013).

Corporate management of information. Various studies show that the management of information is a key determinant of innovation and technological change in firms. Technological change however is crucial in order to modernise old, polluting, inefficient production machinery, and thus respond to environmental regulation and taxes (Bastein et al., 2014). Frishammar \& Hörte (2005) find that the way in which firms manage information determines innovation and efficiency gains to a significant extent. Anderson \& Newell (2004) and Sutherland (1991) too highlight the critical role of information in promoting energy efficiency gains. Disseminating the knowledge about the existence and functionality of new technology requires effective information infrastructure (Howarth \& Andersson, 1993).

Access to information. Firms will fail to improve energy efficiency in response Pigouvian energy taxes, if they lack access to relevant information and technologies. For instance, almost $50 \%$ of small and medium sized enterprises (SMEs) in the EU perceive information constraints as a key obstacle to improving resource efficiency (European Commission, 2013). Struggling to access adequate information, they state that the most useful support mechanism for improving resource efficiency would be either (i) firm specific technical assistance (i.e. consultancy), or (ii) detailed information on technologies and processes for resource efficiency. Firms in lower income economies struggle with access to information to an even larger extent (Figure 1). Rohdin et al. (2007) confirm similar issues, and show that information access constraints are a key obstacle to improving energy efficiency in the Swedish foundry industry. 


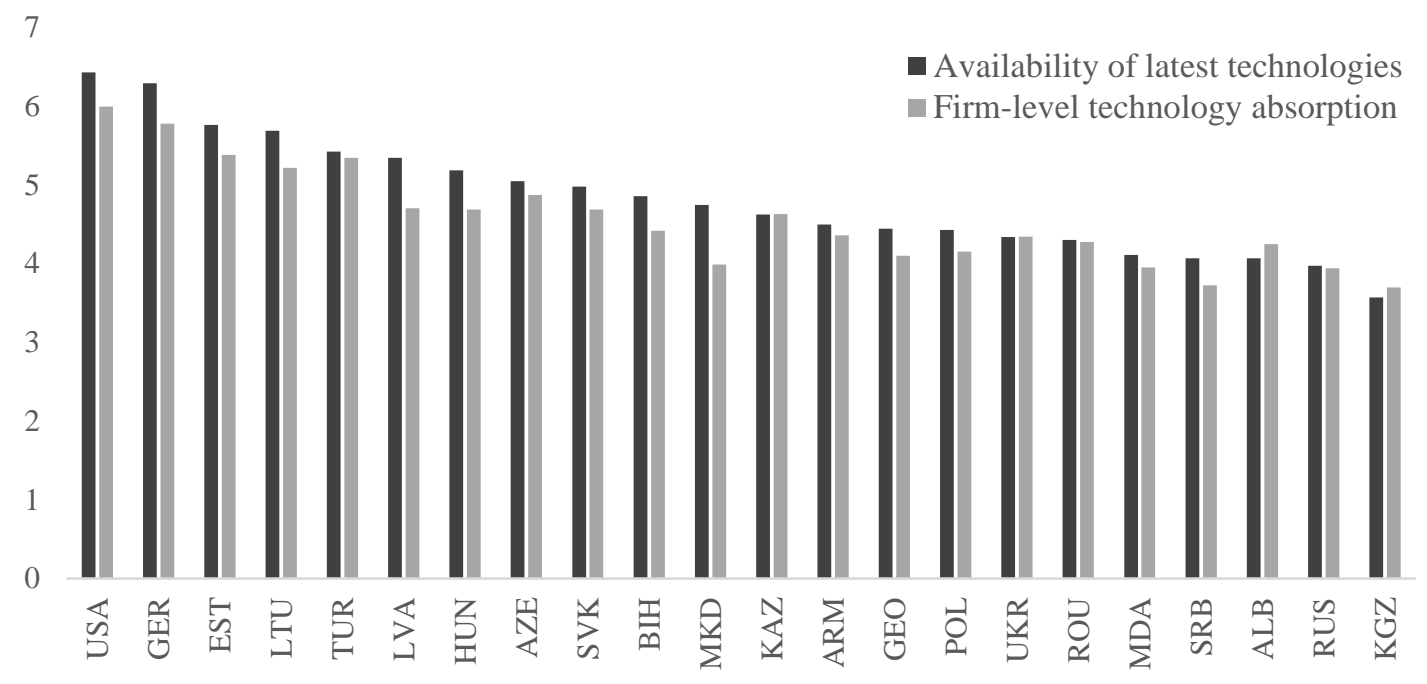

Figure 1 Whether latest technologies (and related information) are available and accessible to firms, determines to a significant extent whether firms adopt such technologies into their operations. This figure shows availability and absorption scores (standardised, where 7 represents the maximum). In global comparison, the USA rank $6^{\text {th }}$ and Kyrgyzstan $138^{\text {th }}$. (World Economic Forum , 2013)

The need for efficiency audits and information programs. Furthermore, Rohdin et al. (2007) find that technical consultants and auditors can play a critical role in overcoming information constraints. In the USA for instance, government financed information services aimed to increase awareness for resource efficiency and offer technical assistance. These programmes included educational workshops, training programmes, advertising, or on-site efficiency audits. Andersen \& Newell (2004) show that these information programmes were very successful in alerting firms of cost-effective efficiency investments, and providing technical information, thus reducing the uncertainty related to adopting new technology. They show that as a consequence of such information programmes, manufacturing firms adopted at least half of the recommended energy efficiency projects. Also in the EU 17\% of (11,000 surveyed) firms state that the difficulty of identifying cost-effective resource efficiency projects is a key obstacle to improving resource efficiency; another $20 \%$ state a "lack of specific expertise" as the main obstacle (European Commission, 2013). This figure is likely to be higher in countries, where technical information and advisory services are less widely available. 


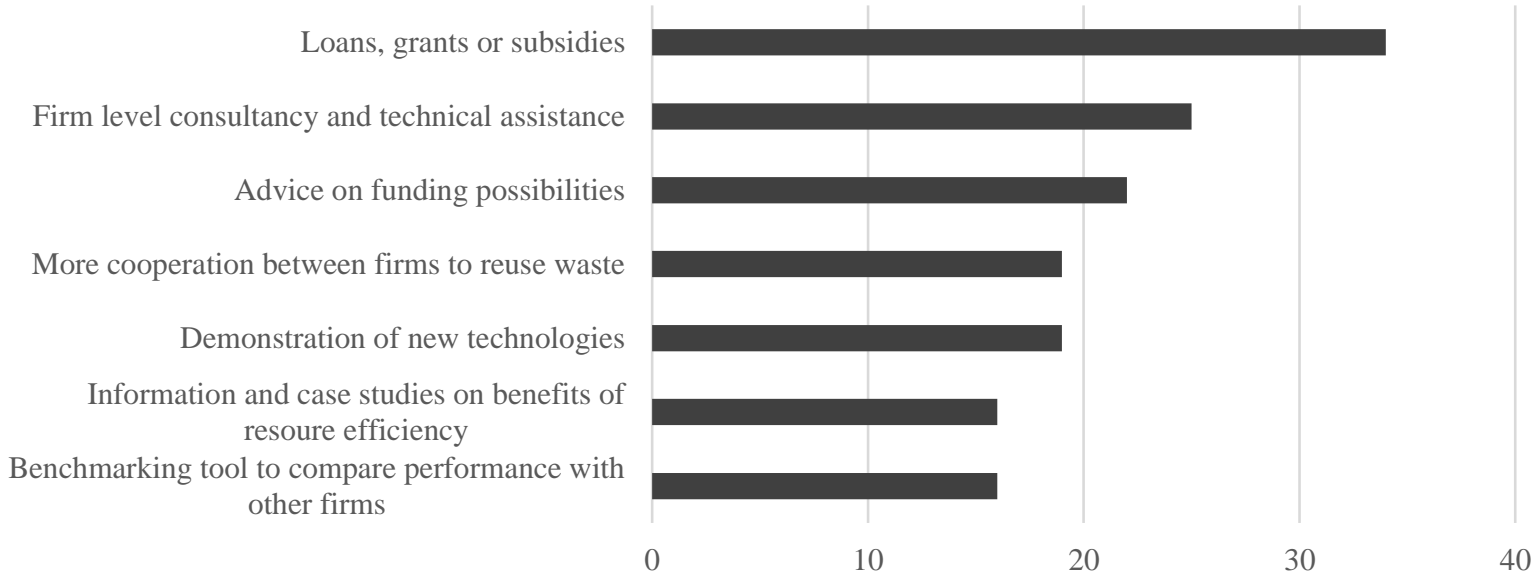

Figure 2 Percentage of firms identifying which measures are most effective in helping them adopt energy and resource efficient technologies. Technical assistance, and different types of information programmes prove to be critical (European Commission, 2013).

DeCanio (1993) emphasises the crucial importance of providing informational services as a complement to standard regulatory instruments and technology investments. Resource and energy efficiency targets, standards, and environmental taxation and regulation more generally cannot trigger the desired effects, if information on alternative, more efficient and cleaner technology is not available. Firms, without the knowledge of effective ways to increase efficiency, will continue to operate within existing information constraints - thus unable to realise the efficiency gains envisaged by regulators.

\subsection{Capacity constraints}

\section{Efficiency investments: Do the characteristics of firms matter?}

Capacity constraints at the individual, firm, or government level may mean that even if information exists (e.g. about the cost-efficiency of resource efficiency solutions), decision makers may not be able or willing to act upon it. ${ }^{2}$ All investments with a positive net present value (NPV) will be implemented by profit maximising firms - at least so claims standard neoclassical theory. In practice however countless examples show that not all such profitable projects are implemented by firms (incl. simple measures such as energy efficient light bulbs, DeCanio \& Watkins, 1998). Bastein et al. (2014) show for a sample of firms from the EU-27 that this lack of investment in efficiency can be explained by various barriers internal to firms. Also the European Commission (2013) identifies firms' technical capacity as a key constraint to the implementation of cost-effective investments in resource and energy efficiency.

In a discrete choice model, DeCanio \& Watkins (1998) show that the characteristics of firms play a key role in determining whether they implement profitable efficiency projects or not. They identify characteristics such as the number of employees, company earnings, or the industrial sector to influence decision making. This shows that the simple availability of a positive NPV project will not ensure its implementation, if the firm is unable or unwilling to do so. Likewise, price signals (due to Pigouvian taxes) may not be enough trigger efficiency investments. In another study DeCanio et al. (1993) show that organisational structure is a key determinant for the effective adoption of innovations, and thus of efficiency gains. They

\footnotetext{
2 This violates the hypothetical condition of perfectly competitive markets that economic agents can make rational decisions based on available information, without incurring transaction costs (such as having to hire external technical consultants).
} 
emphasise that certain organisations are better adapted than others in terms of technical and managerial capacity, thus enabling them to implement efficiency investments more effectively.

\section{At the firm level: Technical expertise and management capacity}

Technical capacity. Technical capacity is essential, in order to effectively assess, install, operate and maintain modern, efficient and clean technology (Durbin, 2004). Complementing environmental taxes with financial support mechanisms for firms to acquire such technology, may not be sufficient if firms lack the technical expertise to install or operate it. This implies that investments in physical infrastructure (e.g. production machinery), which aim at improving resource and energy efficiency, should be accompanied by measures to build technical expertise within firms.

Especially in manufacturing firms improving energy and resource efficiency typically requires technological change. For instance, more modern and efficient machinery, advanced monitoring techniques, and adequate installation and maintenance of machinery are critical to achieving a higher degree of resource productivity. Basic technical knowledge can help managers appreciate the importance of efficiency related investments, and the opportunities associated with them.

\section{Major obstacle to firms: Technical capacity}

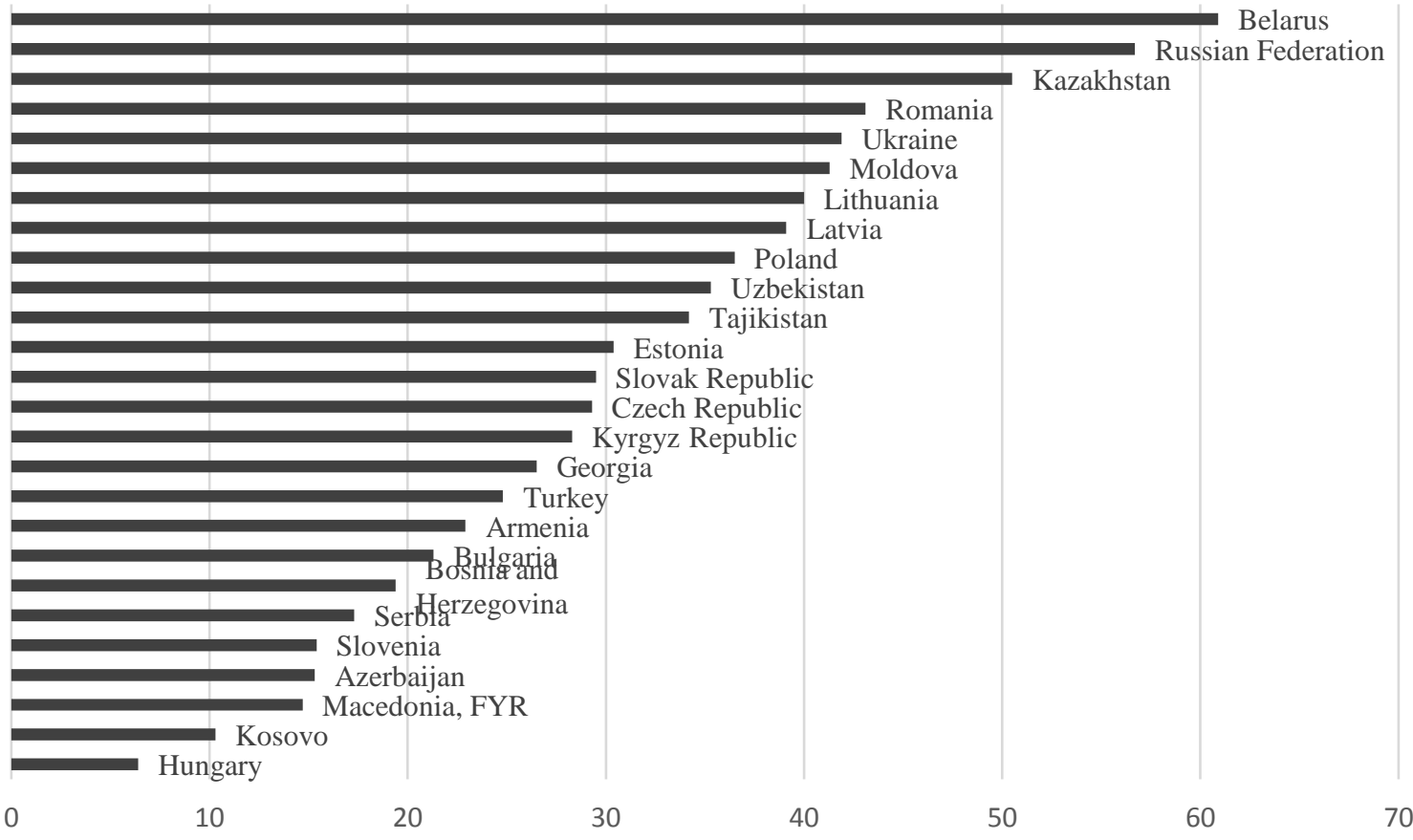

Figure 3 Percentage of manufacturing firms, which state technical capacity to be a major obstacle to their operations (EBRD, 2009).

Regional evidence. In the EU, $20 \%$ of SMEs state the 'lack of specific expertise' to be the biggest obstacle to resource efficiency investments (European Commission, 2013). Another $17 \%$ state that 'difficulties in identifying suitable actions' (i.e. investment opportunities) as the main reason for not being able to invest in resource efficiency. While such specific data is scarce for developing and emerging countries, there is evidence suggesting that technical capacity is a major constraint for firms, even more than for their EU counterparts. In Eastern Europe and Central Asia the majority of manufacturing firms consider technical capacity and an inadequately educated workforce to be a major impediment to their firms' operations (Figure 3) (EBRD, 2010). 
Management capacity. Resource efficiency investments are typically subject to the process of developing or identifying technological innovations, and then implementing them within operating production and consumption systems. Such a process requires forward-looking management, which is able to identify opportunities for efficiency gains (DeCanio \& Watkins, 1998). Indeed the ADB (2013) notes that firms typically perceive 'greening' of their businesses to cause potentially severe disruptions to on-going operations. A regional firm survey conducted in Eastern Europe and Central Asia by the European Bank for Reconstruction \& Development (EBRD, 2010) uses Bloom \& van Reenen's (2007) methodology for investigating management practices in manufacturing firms. The survey shows that firms perform poorly compared to their counterparts in developed economies (Figure 4). While the survey does not focus on resource efficiency directly, such lack of managerial capacity is likely to hamper the effective implementation of efficiency investments, which environmental taxes would necessitate.

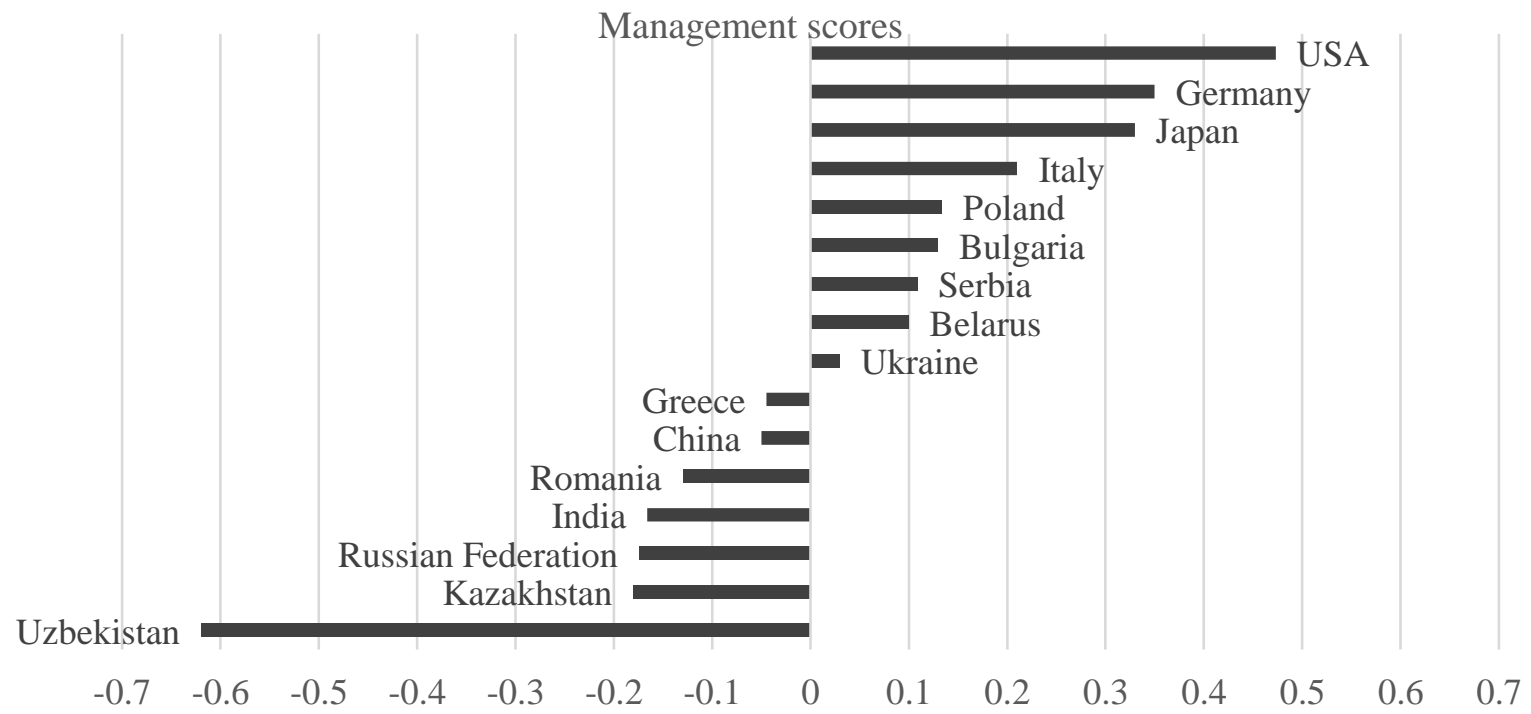

Figure 4 Indicators of managerial capacity (EBRD, 2010)

\section{Institutional capacity}

The external environment for implementing resource and energy efficiency investments and green innovation is determined by the quality of government and administrative capacity. Inadequate government capacity can create major obstacles to firms: corruption, politicised planning, ineffective enforcement, cumbersome bureaucratic processes, and the lack of competitive market regulation can make it difficult for firms to undertake green investments in practice (Acemoglu \& Robinson, 2010; Botems \& Bourgeon, 2005). Certainly these issues are relevant beyond environmental considerations and affect corporate investments and operations more generally. Nevertheless, they can create significant obstacles to the effective functioning of environmental taxes and regulation, and thus require policy makers' attention (Bastein et al., 2014).

The fact that the administrative environment can obstruct green investments, can even be observed in the EU, where administrative capacity is considered comparably high: $26 \%$ of SMEs indicated complex legal or administrative procedures to be a key obstacle to implementing energy and resource efficiency measures (European Commission, 2013). In environments, where government effectiveness, regulatory quality, transparency, and the rule of law are weaker, this percentage can be thought to be considerably higher. 
Emerging and developing countries and resource rich countries in particular tend to perform poorly with respect to various governance indicators (e.g. corruption, or regulatory quality) (World Bank, 2014). Data by the EBRD (2010) shows that between 20\% and 50\% of firms in Eastern Europe and Central Asia perceive lacking administrative capacity to be the single most severe obstacle to their operations.

\section{Biases at the Individual Level}

Awareness. Lacking awareness and understanding of the benefits of energy and resource efficiency and green innovation can lead decision makers to underestimate opportunities. Lacking awareness can typically be attributed to information deficits, though Morris \& Venkatesh (2000) show that age can also influence decisions to adopt technology. These cases provide a direct rationale for implementing targeted information programs to build awareness. Studying a sample of SMEs in Germany, Jordan et al. (2014) identify lacking awareness to be one of the key barriers to investments in resource efficiency.

Behavioural biases. It must also be acknowledged that behavioural biases at the individual level strongly influence decision making, and can prevent the implementation of efficiency measures which would make economic sense. Such factors can partly root in the cultural and socio-economic context. Partly, they can be due to information constraints. Most fundamentally, the failure to act upon information may also reflect behavioural biases, which are simply linked to human nature. DeCanio (1993) for instance notes that 'bounded rationality' can create substantial hurdles within firms to the implementation of energy efficiency measures. Kammerlander (2014) also shows that behavioural biases of individual users can pose significant barriers to the implementation of resource efficiency measures.

\subsection{Financial market constraints}

Especially energy-intensive manufacturing firms may need to implement substantial investments in modernising technology, once an environmental tax (e.g. carbon tax) is imposed. For SMEs in low and medium income economies, cash flows may not permit major investments in efficiency and modernisation, without relying on external credit sources. Allwood et al. (2011) note that businesses, which previously invested heavily in production systems, may face lock-ins due to constrained liquidity, preventing them from investing in modernisation and efficiency gains. In such a situation imposing an environmental tax may have little effect, if firms cannot afford to update or adjust their technology. Also in the EU, $34 \%$ of firms perceive high up-front investments costs to be the most significant obstacle to improving environmental performance (European Commission, 2013). Notably, this is despite various financial support mechanisms available from the EU and its member governments (e.g. the material efficiency programme in Germany; KfW, 2013). In emerging and developing countries such support for green innovation and modernisation is typically more scarce, and financial constraints more substantial.

\section{Uncertain investment payoffs hamper financing}

Once firms face an increased financial burden due to environmental taxes, they may be cautious of taking on the financial risk of investing in expensive new (and unknown) technology, and banks cautious of financing it. When resource and energy efficiency investments are not widely recognised as a way of cutting operating costs and increasing competitiveness, the commercial viability of such investments may not be perceived positively. Various studies show that lacking information and proliferation may lead firms (and local banks) to perceive the benefits 
of energy and resource efficiency investments as uncertain (European Commission, 2013; Anderson \& Newell, 2004; Rohdin, Tholander, \& Solding, 2007). Moreover, banks are likely to perceive investments in efficiency and "greening" as risky, especially if there is no larger scale reporting on the performance of similar projects (Onischka, Liedtke, \& Jordan, 2012). Similarly, unknown technology is associated with risks, as information on reliability and durability may not exist (Anderson \& Newell, 2004).

The viability and profitability of resource related investments also critically depend on commodity prices. For instance, highly volatile resource prices make it difficult for firms to plan investments related to energy or resource efficiency, and reduce the availability and affordability of credit (for details see Section 3.6).

\section{Alternative investments and opportunity costs}

Firms face a broad range of possible investment opportunities, out of which energy or resource efficiency investments are not necessarily the most profitable ones - even if an environmental tax on resource or energy use is imposed. Bleischwitz (2012) for instance notes that labour costs typically constitute a major element of production costs, and shows that firms in the EU have invested heavily in labour productivity. Indeed, when green technology or efficiency investments compete with other investment opportunities for limited funds, the presence of barriers (e.g. capacity or information constraints) may mean that environmental taxes remain relatively ineffective in achieving their environmental objective. More conventional investments (e.g. in labour productivity) may be associated with lower risks and higher returns, thus crowding out funds from investments in clean, low-carbon, efficient (but unknown) technology (Bleischwitz \& Hennicke, 2004; Bleischwitz 2010). Evidence for the European foundry industry shows that the presence of alternative investment and business priorities is a key barrier - especially in an environment of limited financial resources (Trianni et al., 2013).

\section{Structural issues in the banking sector}

Credit markets, particularly in developing and emerging countries, have undergone significant turbulences in the past decade. In Eurasia for instance, turbulences have resulted in a general loss of credibility of local banks, making credit less available and more expensive (Figure 5) (World Bank, 2014). As green investments in hard infrastructure are typically associated with payback periods of several years, turbulences in financial markets make such forward looking investments difficult.

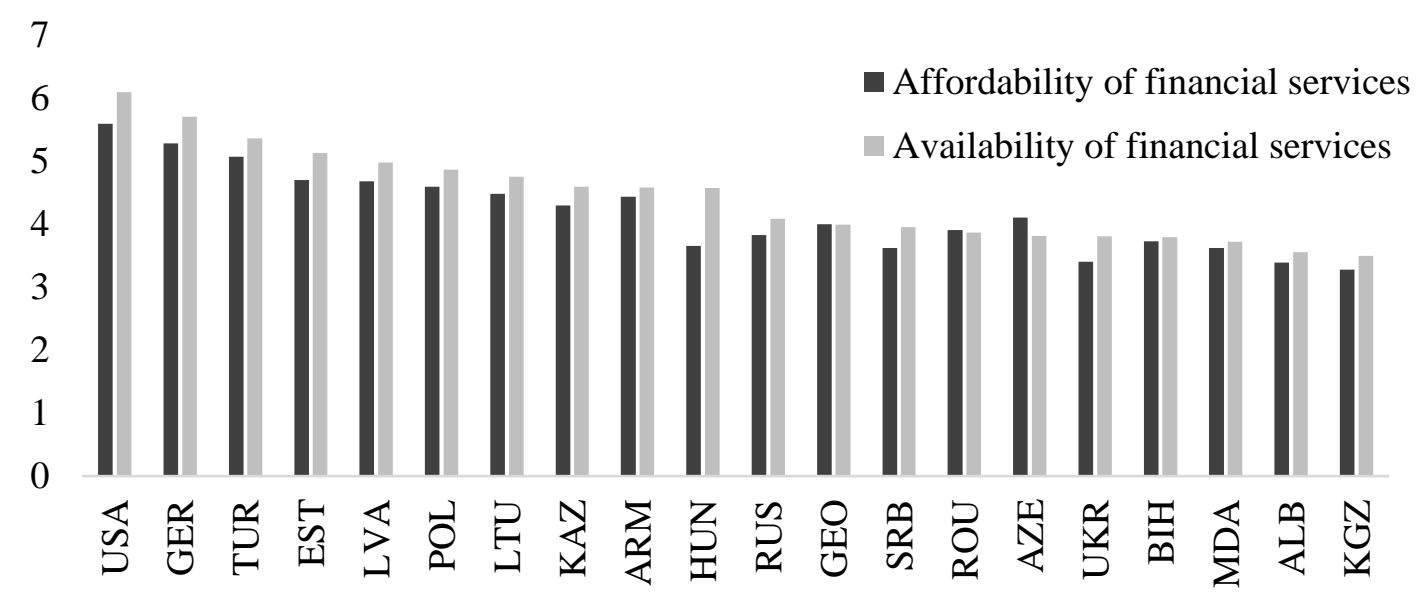

Figure 5 Throughout Eastern Europe and Central Asia, financial services are not only less commonly available, but also more expensive than in high-income countries. Countries scores are standardised to 
a scale from 0 to 7 , where 7 is the best. In global comparison, the USA rank $10^{\text {th }} / 7^{\text {th }}$ (affordability/availability), while Kyrgyzstan ranks $130^{\text {th }} / 131^{\text {st }}$.

As a consequence of structural problems in the banking sector, firms experience difficulties in gaining access to credit for financing efficiency investments and green innovation. Evidence from the EU underscores the importance of financial support mechanisms and availability of credit for funding green investments: In the EU, 20\% of firms undertake energy and resource efficiency investments, because financial public support is available (European Commission, 2013). $24 \%$ of all firms perceive the up-front costs of investments to be the main obstacle to energy and resource efficiency investments.

Even in high-income economies like Sweden, with well-developed credit markets, research has shown that access to capital is the biggest obstacle to efficiency improvements in industrial sectors (Rohdin, Tholander, \& Solding, 2007). Similarly, Jordan et al. (2014) show that in Germany restricted access to financing is a key barrier to investments in resource efficiency. Moreover, the extent to which banks recognise the profitability of energy and resource efficiency projects will also depend on monitoring and reporting practices by firms (Onischka, Liedtke, \& Jordan, 2012).

Some insight can also be gained from the literature on innovation more generally: Hyytinen \& Toivanen (2005) for instance provide empirical evidence that financial constraints can play a significant role in holding back innovation in industries and firms, which are dependent on external financing. They thus argue that in order to promote innovation (and efficiency gains likewise), public interventions ought to complement incomplete or inefficient credit markets.

\subsection{Uncompetitive market structures}

In well-functioning markets, competitive pressures are the key driver of innovation and efficiency gains. Firms can gain a competitive advantage by cutting costs and offering the same product at a lower price than competitors. However, if market structures do not allow free competition, some of the key assumptions of perfectly efficient markets are violated. Thus, if competition is suppressed or certain incumbent firms protected, competitive pressures may not suffice to incentivise investments in energy and resource efficiency, modernisation, or lowcarbon innovation (for a comprehensive review see Requate, 2006). The introduction of environmental taxes in such a setting is likely to be ineffective without complementary policies to foster competition.

Lack of competition. Monopolies and oligopolies may face lesser incentives to cut costs and increase the efficiency of their resource or energy use. The importance of competitive pressures in motivating and driving energy and resource efficiency can be seen in the EU (European Commission, 2013): Out of 11,000 surveyed firms 63\% state that their main motivation for improving energy and resource efficiency are "cost savings" in order to improve competitiveness. Further $18 \%$ of firms directly state "creating a competitive advantage" as their main reason to invest in resource efficiency. Another 9\% state that improving resource efficiency is necessary for "catching up with main competitors" who have already invested in resource efficiency - this also implies that competition plays an important role in disseminating resource efficiency from a first mover to the entire sector. 


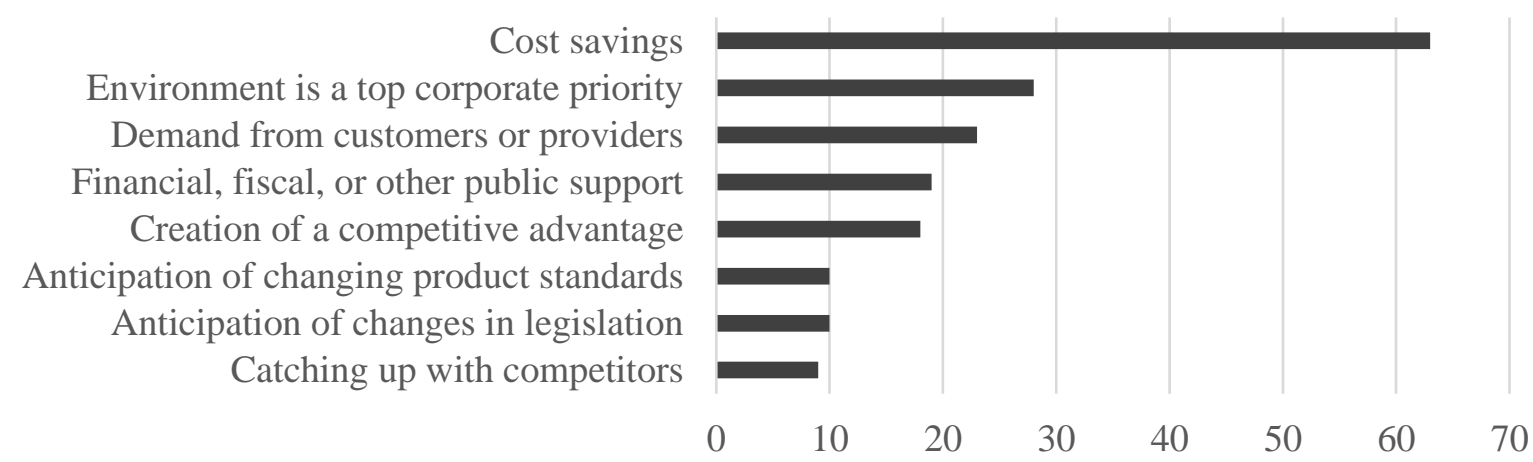

Figure 6 Competitiveness is a key concern for firms investing in resource and energy efficiency (European Commission, 2013).

Emerging and developing countries have a mixed record of actively promoting market competition, indicating shortcomings in regulation and enforcement (World Bank, 2013). Barriers to market entry and exit (e.g. protectionist regulation) often prevent more efficient firms from entering a market, and outperforming less productive incumbents. Firms which are more efficient at complying with environmental standards can operate more cost-effectively in the presence of environmental taxes, but may still be unable to compete with protected incumbents. Markets dominated by oligopolists or large state run (or formerly state run) monopolists may provide fewer incentives for investments towards efficiency gains, as there are fewer or no competitive pressures. Aghion et al. (2002) develop a model on competition and innovation, and find a strong relationship between the two. By showing that competition may increase the incremental profits from innovating, they implicitly emphasise the importance of competitive markets to foster resource related innovations and efficiency gains. Schleifer (1998) also argues that private ownership of firms is more conducive to innovation and efficiency gains than public ownership, which also reduces competitive pressures.

In an uncompetitive market the introduction of environmental taxes may simply mean that firms pass on taxes to consumers in the form of price increases, without improving technology (Castagneto-Gissey, 2014). Consumers may then choose to reduce their demand in response, thus indirectly reducing absolute environmental impacts. However, it would be preferable in terms of aggregate welfare if firms reduced their environmental impacts per unit of output instead, e.g. by investing in efficient and clean production technology.

Trade protectionism. Furthermore, pre-existing market structures and certain industries may be protected from foreign competition through protective trade policies. This can reduce competition from more efficient foreign firms, which reduces competitive pressures and incentives to innovate and increase resource efficiency. It may also obstruct access to foreign technologies and services, which may be crucial for improving resource efficiency - especially when technologies and expertise are not available domestically. Trade restrictions may make it even easier for firms to simply pass on price increases without adjusting technology, as they are shielded from more efficient competitors from abroad.

While direct empirical evidence on the role of trade restrictions in the context of resource efficiency is scarce, the literature on innovation and productivity offers some insights. The relationship between trade liberalisation measures and industrial productivity gains, has been explored in an early theoretical study by Rodrik (1988), and subsequently confirmed by various empirical studies. These studies argue that by being able to import modern technology from abroad, firms are able to realise efficiency gains: For instance, firm-level evidence from Turkey 
suggests that following a number of trade liberalisation measures in the 1980's, innovation among Turkish manufacturing firms increased significantly (Pamukcu, 2003). Most notably, improvements in innovation took the form of imported machinery, enabling increases in firm productivity. Similar results are presented by Krishna \& Mitra (1998), who show that trade liberalisation measures in India increased competition and the growth rate of productivity across various industrial sectors.

\subsection{Fiscal mismanagement}

Most adverse social and environmental impacts from resource use and energy production fail to be reflected in market prices of these commodities (Allwood et al., 2011, on natural resources specifically). In order to account for such externalities, corrective taxation and subsidy policy can direct firms and households towards desired economic outcomes by providing financial incentives, which the market per se may fail to provide. Fiscal mismanagement however can aggravate the problems.

\section{Subsidies}

One common example of a distortive fiscal policy is the provision of resource subsidies, which ease the usage or increase the commercial attractiveness of a specific resource, for instance by artificially suppressing the local price of a resource (Yeo et al., 2010). As a consequence, end users face lower usage costs, and tend towards overconsumption and inefficient usage of the resource. In addition to environmental and efficiency issues, resource subsidies cause an increasing burden to national accounts: As international resource prices increase (in levels and volatility), providing price subsidies becomes increasingly expensive and unpredictable.

Both energy and producer subsidies directly undermine the effectiveness of environmental taxes, and can be considered to be the policy antithesis to Pigouvian taxes. In fact, many countries (including G20 economies) have parallel fiscal systems in place, which both subsidise the use or extraction of polluting fuels (especially fossils) and simultaneously impose environmental taxes upon them (Whitley, 2013; OECD, 2015). The ADB (2013) identifies subsidies as a key barrier to energy efficiency investments in the Asia Pacific region. There is evidence from Yemen, Egypt and India that energy subsidies play a central role in exacerbating inefficient usage of other scarce resources, especially water (Commander et al., 2015).

At the same time, it must also be noted that prudent subsidy schemes, targeted at improving competitiveness (rather than preserving inefficiencies), can play a substantial positive role e.g. by modernising inefficient industries, or supporting low-carbon technology (Fischer et al, 2015). Following the same rationale the Chinese government for instance announced $\$ 6$ bn in investments in the steel sector in 2000, in order to introduce modern technologies, and improve efficiency (US Dept. of Commerce, 2001). Similarly, the fuel subsidy reform in Iran (in Dec. 2010) was accompanied by targeted financial assistance to firms to help them restructure and modernise in response to increase energy costs (Salehi-Isfahani et al., 2014; IMF, 2013).

Energy subsidies and resource efficiency. As Allwood et al. (2011) note lower energy prices (e.g. due to subsidies) may increase the overall demand for energy intensive materials ${ }^{3}$. In fact, fossil fuel subsidies can directly impact on the resource efficiency of firms, since energy and resource efficiency are closely linked. Essentially, this means that if energy is cheap due to fossil fuel subsidies, the processing of materials is cheap, and thus energy prices play a lesser

\footnotetext{
${ }^{3}$ For other less energy intensive materials other factors, such as labour costs, can play an important role too.
} 
role in motivating resource efficiency. Particularly in energy intensive industries, fossil fuel subsidies can thus reduce the incentives to improve resource efficiency.

A concrete example can illustrate this issue: For each ton of output, the Russian foundry industry is estimated to use 3 times more energy, 3.6 times more sand, and 161 times more water than comparable EU plants (IFC, 2010). Thus, if Russian plants were to match the level of resource efficiency in European plants, they would be able to save close to 20,000GWh of energy, $5.7 \mathrm{~m}$ tons of sand, and $879 \mathrm{~m}$ cubic meter of water - corresponding to $\$ 3.3 \mathrm{bn}$ of savings per annum (IFC, 2010). However, Russia subsidises energy more than any other high-income high-emitting country $\left(\mathrm{E} 11^{4}\right)$ at $\$ 31.3 \mathrm{bn}$ in 2010 (Whitley, 2013). These subsidies play a significant role in lowering energy costs, which are 54\% lower than for instance in Germany (IFC, 2010). Thus, Russian foundry plants would face considerably higher incentives to invest in resource efficiency, if energy prices were not subsidised.

Industry subsidies. Governments may also choose to subsidise specific resource and energy intensive industries. Such industry subsidies (i.e. paid to producers) are far less documented, partly because of the many non-transparent forms they can take. Nevertheless, Legeida (2002) argues that by granting subsidies to inefficient industries, and thus artificially increasing their competitiveness, governments prolong existing resource inefficiencies. The steel industry, for instance in Russia, Ukraine and Poland, has been documented to receive substantial preferential treatment by the state, for instance through low interest loans, tax privileges, or write-offs of tax arrears (Legeida, 2002). Such advantages may not come as a surprise as the steel sectors in these countries faced substantial structural problems such as over-capacity, over-employment, and inefficient, obsolete machinery.

\subsection{Uncertainty, volatility and instability}

Commodity price volatility. While uncertainty per se does not necessarily cause market failures and inefficiencies, it may exacerbate existing ones. Even if environmental taxes increase average commodity or energy prices, firms may refrain from large capital investments (e.g. in energy efficient technology) if prices are volatile. Volatile resource prices can make the payoffs from efficiency investments uncertain, thus affecting the expected profitability of investments and the ability to finance them. If energy and resource prices are high, investments in the conservation and efficient usage of energy and resources prove more attractive, as payback periods on investments are shorter. Low prices prolong payback periods, making investments less attractive. Furthermore, decreasing commodity prices can pose risks for firms, if efficiency investments have already been made: annual payoffs from the investment will be reduced, while high interest rates remain. Overall, uncertain prices will make obtaining credit for such investments even more difficult and expensive than is already the case.

This issue has been explored by Pindyck (1990), who showed that irreversible investments (e.g. in physical infrastructure with large sunk costs) are particularly sensitive to cash flow risks and uncertainty. Pindyck (2006) relates this issue explicitly to environmental policies and emphasises the ubiquity of uncertainty surrounding environment related investments (including those in energy efficiency). Zhao (2003) too shows that the incentives for firms to make irreversible investments in efficient technologies is reduced when cost uncertainties increase.

At the same time it must be noted that increasing resource and energy efficiency is an important way to reduce the dependency on resources and the exposure to volatile prices, i.e. to hedge against price uncertainty (e.g. Ebrahim et al. (2014) in the context of oil). This implies that the

\footnotetext{
${ }^{4}$ The E11 country grouping is defined as Australia, Canada, France, Germany, Japan, Italy, Poland, Russia, Spain, United Kingdom, and United States.
} 
implementation of energy and resource efficiency measures can act as a hedging measure against price volatility, and at the same time be obstructed by price volatility.

Policy credibility. A lack of policy credibility is typically a consequence of frequent changes or time-inconsistency in policy making (World Bank, 2013). For instance, the implementation of green subsidies (e.g. for the installation of clean and efficient technology) may be a right step per se in favour of resource and energy efficiency. However, it must be paired with credibility. A typical example in the energy sector are feed-in tariffs, which aim to incentivise investments into renewable energy. If such tariffs lack long term credibility, investors may not take up the offer. Similarly, if firms do not expect carbon taxes to persist in the long term, they are less likely to invest in low carbon infrastructure (Brunner et al., 2012). Farzin \& Kort (2000) show that such uncertainty surrounding environmental regulation raises firms' discount rate and results in underinvestment in clean technology. Moreover, Krysiak (2008) shows that firms not only invest less (i.e. lower quantity) in efficient technologies, but also select socially suboptimal technology (i.e. lower quality).

Economic, political, and corporate context. Besides the above types of uncertainty, which are directly associated with green investments (e.g. resource prices, or reliability of relevant regulation), more general uncertainties will also affect investment decisions (incl. political conflict, economic crises, etc.). This is not least due to their impact on discount rates (Gollier, 2002). If uncertainties are perceived to be more significant, future benefits from efficiency investments may need to be discounted more (Pindyck, 1990). This negatively affects the costbenefit ratio of green investments, since benefits are typically spread throughout the future, while costs are mostly up-front.

\section{Policy instruments for improving resource efficiency}

\section{Need for complementary policies}

Overall, if barriers are strong, the absence of complementary policies may mean that environmental taxes fail to trigger significant improvements of energy and resource efficiency, and overall environmental performance. In fact, this argument extends to environmental policies more broadly (including command \& control regulation, quotas, and trading schemes). Avner et al. (2014) demonstrate the synergies between carbon or fuel taxes and complementary infrastructure investments: If investments in public transport infrastructure are made, commuters are more likely to respond to increasing fuel prices by switching from cars to lowcarbon public transport (thus improving the fuel efficiency of their commute). In a hypothetical scenario, in which no public infrastructure is provided, the authors estimate that carbon taxes would need to be $115 € / \mathrm{tCo} 2$ to achieve a $6 \%$ reduction in carbon emissions from commuting. However, if public transport infrastructure is made available as a complement to carbon taxes, the same emission reduction can be achieved at $65 € / \mathrm{tCo} 2$.

To cite another example, the European Union's directives on waste and landfills (European Commission, 1999; 2008) were adopted to reduce the negative externalities resulting from waste disposal, and has had a profound impact on the way waste in the EU is recycled or disposed. In the UK, landfill taxes have been one of the key instruments for implementing the Landfill Directive. By increasing the cost of disposal, waste treatment and recycling technologies become commercially more attractive, and less waste is produced in the first place. In the absence of waste tariffs, low disposal costs lead firms to produce 'excess' waste -often associated with significant environmental externalities (Morrisa et al., 1998). However, for these taxes to be effective, the EU Waste Framework Directive defines complementary targets which pertain to institutional context (incl. accountabilities and enforcement) and 
capacity building, and are complemented by financial support mechanisms (European Commission, 1999; 2008).

Fay et al. (2015) argue that complementary policies for supporting environmental policies (e.g. externality taxes) cover a wide range and include government support for research, development and innovation, performance standards, fiscal incentives for green investments, and social policies. Grubb \& Ulph (2002) also argue that there can be significant synergies between environmental, technological and innovation policies. These policy types should however, be regarded as complements rather than substitutes (Fischer, 2008). Lecuyer \& Quirion (2013) show that it can be socially optimal to implement complementary policies to carbon pricing in order to mitigate uncertainty.

We provide further evidence in support of complementary policies, as Pigouvian taxes may be less effective at achieving their environmental objectives, if end-users and firms have restricted options to respond to environmental taxes. While Pigouvian taxes may address the market failure of environmental externalities, other market failures remain - such as the public goods nature of R\&D and technological innovation. Popp (2006) shows that this combination of market failures requires a combination of policy measures. Addressing complementary policies can thus help to mitigate such barriers and reduce the costs of environmental price instruments (and thus increase public acceptability).

\section{Addressing distortions and complementing environmental taxes}

The variety of investment barriers to improving efficiency and environmental performance suggests the need for a carefully designed package of complementary policy measures, including efficiency audits, training, hard infrastructure investments, waste management and recycling schemes, as well as more structural regulatory reforms. Considering pollution, acute environmental destruction, and near capacity landfills, short and medium term measures for assisting firms to reduce their adverse environmental impacts are critical.

At the same time the market and government failures, which led to investment barriers in the first place must also be addressed, as they will create new inefficiencies and perpetuate existing ones (Reddy et al., 2013; Cagno et al., 2013). This is important in order to achieve a larger scale enhancement of resource and energy efficiency, as well as to sustain efficiency gains and green development over time (Bleischwitz, 2012). Sorrell \& Sijm (2003) argue that carbon pricing can be at the heart of such a policy mix, though trade-offs due to policy interactions may exist. Fankhauser et al. (2010) also suggest that combining multiple climate policy instruments bears risks to efficiency - though they mainly focus on combing different carbon pricing instruments, rather than complementary policies more broadly.

Essentially, this prescribes two possible approaches for complementing environmental pricing instruments, and tackling firms' investment barriers: (i) Addressing the immediate 'Symptoms' of investment barriers, i.e. help firms to deal with and overcome the adverse effects of preexisting investment barriers (e.g. supply specific technical information needed for increasing energy efficiency in a firm/sector); and (ii) Addressing the underlying 'Causes' of investment barriers, i.e. resolving the pre-existing market failures and structural inefficiencies, which cause the barriers in the first place (e.g. fix overall information infrastructure and technology dissemination systems). These approaches are not mutually exclusive, and both need to be part of a comprehensive strategy for resource efficiency.

\section{Complementary measures: intervention levels and types}


Measures for complementing environmental taxes can broadly be distinguished into micro and macro level interventions: i.e. firm level measures, which support firms in overcoming the above mentioned investment barriers, and more comprehensive macro level measures, which reform structural deficiencies and inefficiencies of the overall system (see Table 2).

Complementing environmental taxes at the micro level means to support specific firms with the implementation of efficiency projects, modernisation and green innovation - especially when firms may otherwise struggle to implement necessary changes. Such support comprises both technical assistance (especially for building capacity), as well as financial assistance which can enable concrete efficiency enhancing measures at the firm level in the presence of financial barriers (DeCanio, 1993; Anderson \& Newell, 2004).

Overall, micro level measures can be effective in facilitating quick efficiency gains in targeted industries, and may (eventually) lead to a bottom-up improvement of sector-wide environmental performance. Firm level measures are however less suitable for resolving the structural causes of barriers to green investment.

Complementing environmental taxes at the macro level means to implement policy and regulatory reforms, which address incentive structures, and improve the investment environment within which firms operate (Reddy et al., 2013). As at the firm level, macro measures comprise non-monetary and monetary ones likewise.

\begin{tabular}{|c|c|c|c|c|}
\hline \multicolumn{5}{|c|}{ Complementary policy measures and interventions } \\
\hline & \multicolumn{2}{|c|}{ Micro (i.e. firm) level } & \multicolumn{2}{|c|}{ Macro level } \\
\hline & Technical Assistance & Project Lending & $\begin{array}{c}\text { Technical Assistance \& } \\
\text { Policy Reform }\end{array}$ & $\begin{array}{l}\text { Development } \\
\text { Lending }\end{array}$ \\
\hline $\begin{array}{l}\text { Addressing } \\
\text { the } \\
\text { Symptoms } \\
\text { of Market } \\
\text { Distortions }\end{array}$ & $\begin{array}{l}\text { - Efficiency audits } \\
\text { - Identification of } \\
\text { specific projects }\end{array}$ & $\begin{array}{l}\text { - Installation of } \\
\text { cleaner production } \\
\text { infrastructure } \\
\text { - Modernisation of } \\
\text { production } \\
\text { processes } \\
\text { - Retro-fitting }\end{array}$ & $\begin{array}{l}\text { Building strategies to } \\
\text { improve material } \\
\text { recovery from waste }\end{array}$ & \\
\hline $\begin{array}{l}\text { Addressing } \\
\text { the } \\
\text { Structural } \\
\text { Causes of } \\
\text { Investment } \\
\text { Barriers }\end{array}$ & $\begin{array}{l}\text { - Building technical } \\
\text { and managerial } \\
\text { capacity } \\
\text { - Establish systems } \\
\text { for monitoring } \\
\text { performance \& info. } \\
\text { disclosure, } \\
\text { - Awareness building } \\
\text { - Disseminate } \\
\text { information \& } \\
\text { technology } \\
\text { - Foster R\&D and } \\
\text { innovations }\end{array}$ & $\begin{array}{l}\text { - Infrastructure for } \\
\text { information sharing } \\
\text { and training } \\
\text { - Infrastructure to } \\
\text { link markets (e.g. } \\
\text { transport } \\
\text { infrastructure } \\
\text { linking supply \& } \\
\text { demand for } \\
\text { recycled materials) }\end{array}$ & $\begin{array}{l}\text { - Institution building } \\
\text { - Fiscal policy reforms } \\
\text { (e.g. energy subsidy } \\
\text { reforms, waste tariffs) } \\
\text { - Legal requirements for } \\
\text { monitoring and } \\
\text { disclosure of efficiency } \\
\text { performance } \\
\text { - Strengthening the } \\
\text { financial sector } \\
\text { - Dedicated lending } \\
\text { facilities for resource } \\
\text { efficiency projects } \\
\text { - Foster competition }\end{array}$ & $\begin{array}{l}\text { - Developing } \\
\text { markets and } \\
\text { infrastructure } \\
\text { - Strengthen } \\
\text { macro-economy } \\
\text { - Institution } \\
\text { building } \\
\text { - Direct support to } \\
\text { research \& } \\
\text { innovation } \\
\text { - Green growth } \\
\text { strategies }\end{array}$ \\
\hline
\end{tabular}

Table 2 This typology presents a toolbox for micro and macro interventions, which can complement price based environmental policy instruments. The categorisation is indicative and not definite: For instance, micro level measures may eventually lead to more structural macro improvements. 


\section{Conclusion - what it means for policy makers}

Environmental taxes are the policy instruments favoured by economists, as they are an efficient way of imposing the social and environmental costs of certain activities on those responsible. However imposing externality taxes per se does not necessarily cause firms (or end-users) to reduce harmful practices. It is critical to recognize that various market failures and distortions confront firms with investment barriers. These barriers mean that firms shoulder the environmental tax burden without being able (or willing) to improve environmental performance, or even passing it on to consumers.

In practice, these barriers can prevent firms from investing in cleaner, more modern and efficient production. As a consequence well intentioned environmental taxes (and in fact environmental policies more generally) may fall short of their objective of triggering a reduction of adverse environmental impacts. This paper presents evidence suggesting that these barriers can be substantial and wide spread in practice. To successfully overcome this 'web' of barriers, it is critical to complement environmental policies, with measures for mitigating such investment barriers (Dijk \& Kemp, 2016).

Having presented a comprehensive overview of the most common reasons why firms may respond less to environmental taxes than policy makers envisage, we now conclude that in order for environmental taxes to be effective, they need to be designed and implemented with additional measures, which address the adverse role of investment barriers. For this purpose, this paper suggests a two-tiered multi-level policy toolbox: micro (i.e. firm level) and macro level measures, financial and technical support measures, short-term measures for immediate mitigation of investment barriers, as well as longer-term measures for addressing structural causes. Overall, by identifying and addressing investment barriers, policy makers can increase the prospects for environmental and resource taxes to successfully mitigate externalities and raise revenue.

\section{Acknowledgements}

This paper is partly based on a research partnership between the Institute for Sustainable Resources at University College London (UCL ISR) and the European Bank for Reconstruction and Development (EBRD), and the associated policy report by Flachenecker \& Rentschler (2015). It benefited from extensive comments from and discussions with Craig Davies, Paul Ekins, Nigel Jollands, and Gianpiero Nacci. Comments by seminar participants at the EBRD in December 2014, and by anonymous referees are gratefully acknowledged. The conceptual framework of this paper is inspired by Chapter 2 of the World Bank's World Development Report 2014 (Typology of obstacles to risk management) by Stéphane Hallegatte.

\section{References}

Acemoglu, D., Aghion, P., Bursztyn, L., Hemous, D., (2012). The Environment and Directed Technical Change. American Economic Review. 102, 131-166.

Acemoglu, D., \& Robinson, J. (2010). The Role of Institutions in Growth and Development. In D. Brady \& M. Spence (Eds.), Leadership and Growth (pp. 135-164). Washington DC: The World Bank.

ADB (2013). Same Energy, More Power: Accelerating Energy Efficiency in Asia. Manila: Asian Development Bank

Aldy, J. E., Krupnick, A. J., Newell, R. G., Parry, I. W., \& Pizer, W. A. (2010). Designing Climate Mitigation Policy. Journal of Economic Literature, 48(4), 903-934.

Allwood, J. M., Ashby, M. F., Gutowski, T. G., \& Worrell, E. (2011). Material efficiency: A white paper. Resources, Conservation and Recycling, 55(3), 362-381. 
Aghion, P., Bloom, N., Blundell, R., Griffith, R., \& Howitt, P. (2002). Competition and Innovation: An Inverted U Relationship. NBER Working Paper Series, No. 9269.

Anderson, S., \& Newell, R. (2004). Information programs for technology adoption:. Resource and Energy Economics, Vol. 26, pp. 27-50.

Avner, P., Rentschler, J., \& Hallegatte, S. (2014). Carbon Price Efficiency Lock-in and Path Dependence in Urban Forms and Transport Infrastructure. World Bank Policy Research Working Papers, 6941.

Baron D. (1985), Regulation of Prices and Pollution under Incomplete Information, Journal of Public Economics, 28, 211-231.

Bastein, T., W. Koers, K. Dittrich, J. Becker, F. Lopez (2014) Business barriers to the uptake of resource efficiency measures. POLFREE Deliverable 1.5. Policy Options For a Resource Efficient Economy (POLFREE)

Blaug, M. (2007). The fundamental theorems of modern welfare economics, historically contemplated. History of Political Economy, 39(2), 185.

Bleischwitz, R., \& Hennicke, P. (Eds.). (2004). Eco-efficiency, regulation, and sustainable business: towards a governance structure for sustainable development. Edward Elgar Publishing.

Bleischwitz, R. (2010). International economics of resource productivity - Relevance, measurement, empirical trends, innovation, resource policies. International Economics and Economic Policy, Vol. 7(2-3), 227-244.

Bleischwitz, R. (2012). Towards a Resource Policy - Unleashing Productivity Dynamics and Balancing International Distortions. Mineral Economics. Vol. 24(2). pp 135-144

Bloom, N., \& van Reenen, J. (2007). Measuring and Explaining Management Practices Across Firms and Countries. Quarterly Journal of Economics , Vol. 122(4), pp. 1351-1408.

Bontems, P., \& Bourgeon, J. M. (2005). Optimal environmental taxation and enforcement policy. European Economic Review, 49(2), 409-435.

Bovenberg, L., \& Goulder, L. H. (1996). Optimal Environmental Taxation in the Presence of Other Taxes: General-Equilibrium Analyses. The American Economic Review, 86(4), 985-1000.

Bovenberg, A. L. (1999). Green Tax Reforms and the Double Dividend: an Updated Reader's Guide. International Tax and Public Finance, 6(3), 421-443.

Brunner, S., Flachsland, C., \& Marschinski, R. (2011). Credible commitment in carbon policy. Climate Policy, Vol. 12(2), 255-271.

Cagno, E., E. Worrell, A. Trianni, G. Pugliese (2013). A novel approach for barriers to industrial energy efficiency, Renewable and Sustainable Energy Reviews, Vol. 19, Pages 290-308

Castagneto-Gissey, G. (2014). How competitive are EU electricity markets? An assessment of ETS Phase II. Energy Policy, Vol. 73, 278-297.

Commander, S., Z. Nikolski, M. Vagliasindi (2015). Estimating the Size of External Effects of Energy Subsidies in Transport and Agriculture. World Bank Policy Research Working Papers, 7227

D'Amato, A., Dijkstra, B.R. (2015,) Technology choice and environmental regulation under asymmetric information, Resource and Energy Economics, vol. 41, pages 224-247

DeCanio, S. (1993). Barriers within firms to energy-efficient investments. Energy Policy , pp. $906-914$.

DeCanio, S., \& Watkins, W. (1998). Investment in Energy Efficiency: Do the Characteristics of Firms Matter? The Review of Economics and Statistics, Vol. 80(1), pp. 95-107.

DeCanio, S., Dibble, C., \& Keyvan, A.-A. (2000). The Importance of Organizational Structure for the Adoption of Innovations. Management Science, Vol. 46 (10), pp.1285-1299.

Dijk, M., R. Kemp (2016) Understanding the Web of Constraints on Resource Efficiency in Europe. Policy Brief March 2016. Policy Options For a Resource Efficient Economy (POLFREE)

Domenech, T., Bleischwitz, R., Ekins, P., O’Keeffe, M., Drummond, P., 2014, Lessons from the EU policy experiences, POLFREE Deliverable 1.2. Policy Options For a Resource Efficient Economy (POLFREE)

Durbin, S. (2004). Workplace Skills, Technology Adoption and Firm Productivity: A Review. New Zealand Treasury Working Paper. 04/16. September 2004

Ebrahim, Z., Inderwildi, O. R., \& King, D. a. (2014). Macroeconomic impacts of oil price volatility: mitigation and resilience. Frontiers in Energy, 8(1), 9-24.

EBRD. (2010). EBRD Management, Organisation, and Innovation (MOI) Survey. From European Bank for Reconstruction and Development: http://www.ebrd.com/pages/research/economics/data/moi.shtml 
European Commission (1999). Council Directive 1999/31/EC of 26 April 1999 on the Landfill of Waste. Brussels: European Commission.

European Commission (2008). Directive 2008/98/EC of the European Parliament and the Council of 19 November 2008 on Waste. Brussels: European Commission.

European Commission (2011). Roadmap to a Resource Efficient Europe. Communication from the Commission to the European Parliament, the Council, the European Economic and Social Committee and the Committee of the Regions.

European Commission (2012). Directive 2012/27/EU of the European Parliament and the Council of 25 October 2012 on Energy Efficiency. Brussels: European Commission.

European Commission (2013). Eurobarometer: SMEs, Resource Efficiency and Green Markets. Brussels: European Commission.

Fankhauser, S., Hepburn, C., Park, J. (2010), Combining multiple climate policy instruments: how not to do, Climate Change Economics, vol. 1(3), pages 209-225

Farzin, Y.H., Kort, P.M. (2000), Pollution Abatement Investment When Environmental Regulation Is Uncertain, Journal of Public Economic Theory, Vol. 2(2), pages 183-212

Fischer, C. (2008) Emissions pricing, spillovers, and public investment in environmentally friendly technologies, Energy Economics, vol. 30(2), pages 487-502

Fischer, Carolyn; M., Greaker; K.E. Rosendahl (2015). Strategic subsidies for renewable energy. Conference Paper. Green Growth Knowledge Platform (GGKP) Third Annual Conference. 29-30 January, 2015

Flachenecker, F., \& J. Rentschler (2015), Investments in Resource Efficiency - Costs and Benefits, Investment Barriers, and Intervention Measures. A report commissioned by the European Bank for Reconstruction and Development (EBRD). London: University College London (UCL)

Frishammar, J., \& Hörte, S. (2005). Managing External Information in Manufacturing Firms: The Impact on Innovation Performance. The Journal of Product Innovation Management, Vol. 22(3), pp. 251266.

Gillingham, K., Newell, R. G., \& Palmer, K. (2009). Energy Efficiency Economics and Policy. Annual Review of Resource Economics, Vol. 1(1), pp. 597-620.

Gollier, C. (2002). Discounting an uncertain future. Journal of Public Economics, pp. 149-166.

Goulder, L. (2013) Climate change policy's interactions with the tax system. Energy Economics 40 (2013) S3-S11

Grubb, M., Ulph, D. (2002), Energy, the Environment, and Innovation, Oxford Review of Economic Policy, vol. 18(1), pages 92-106.

Hallegatte, S., Fay, M., \& Vogt-Schilb, A. (2013). Green Industrial Policies - When and How. World Bank Policy Research Working Papers, 6677.

Hyytinen, A., \& Toivanen, O. (2005). Do financial constraints hold back innovation and growth? Evidence on the role of public policy. Research Policy, Vol. 34(9), pp. 1385-1403.

Howarth, R., \& Andersson, B. (1993). Market Barriers to Energy Efficiency. Energy Economics, pp. 262272.

IFC. (2013). Municipal Solid Waste Management: Opportunities for Russia. Washington DC: International Finance Corporation.

IMF. (2013). Energy Subsidy Reform: Lessons and Implications. Washington DC: International Monetray Fund.

Jordan, N. D., Lemken, T., \& Liedtke, C. (2014). Barriers to Resource Efficiency Innovations and Opportunities for Smart Regulations - the Case of Germany. Environmental Policy and Governance, 24(5), 307-323. doi:10.1002/eet.1632

Kammerlander, M. (2014). Individual Behavioural Barriers to Resource Efficiency (2014), Deliverable 1.6 of POLFREE project, SERI, MU-ICIS and UCL http://www.polfree.eu/publications/publications2014/Del_1.6_FINAL_20VERSION_clean_20lay-out_20-2.pdf

KfW (2013). BMU-Umweltinnovationsprogramm: Neuer Förderschwerpunkt „Materialeffizienz in der Produktion “. From Kreditanstalt für Wiederaufbau.

Kostka, G., Moslener, U., Andreas, J., (2013). Barriers to increasing energy efficiency: evidence from small-and medium-sized enterprises in China. Journal of Cleaner Production. Vol.57, pages 5968. 
Krishna, P., \& Mitra, D. (1998). Trade liberalization, market discipline and productivity growth: new evidence from India. Journal of Development Economics, Vol. 56(2), pp. 447-462.

Krysiak, F.C. (2008), Prices vs. quantities: The effects on technology choice, Journal of Public Economics, vol. 92(5-6), pages 1275-1287

Laffont, J. J. (1994). Regulation of Pollution with Asymmetric Information. Nonpoint Source Pollution Regulation: Issues and Analysis, 39.

Legeida, N. (2002). The Economic Implications of Government Support for the Steel Industry: The Case of Ukraine. Association for Studies in Public Economics - The Fifth International Conference on "Public Sector Transition".

Lipsey, R., K. Lancaster (1956). The General Theory of Second Best. The Review of Economic Studies Vol. 24, No. 1 (1956 - 1957), pp. 11-32

Montero, J.P. (2002), Permits, Standards, and Technology Innovation, Journal of Environmental Economics and Management, Vol. 44(1), pages 23-44

Morris, M.G., V. Venkatesh (2000). Age differences in technology adoption decisions: Implications for a changing work force. Personnel Psychology. Vol. 53, pp. 375-403.

Morrisa, J., Phillips, P., \& Read, A. (1998). The UK Landfill Tax: an analysis of its contribution to sustainable waste management. Resources, Conservation and Recycling, Vol. 23(4), pp. 259-270.

OECD (2004). Principles of Corporate Governance. Paris: OECD.

OECD (2015). OECD Inventory of Support Measures for Fossil Fuels 2015. Paris: OECD

Onischka, M., Liedtke, C., \& Jordan, N. (2012). How to sensitize the financial industry to resource efficiency considerations and climate change related risks. Journal of Environmental Assessment Policy and Assessment, Vol.14 (3).

Pamukcu, T. (2003). Trade Liberalization and Innovation Decisions of Firms: Lessons from Post-1980 Turkey. World Development, Vol. 31(8), pp. 1443-1458.

Parry, I., Evans, D., \& Oates, W. E. (2014). Are energy efficiency standards justified? Journal of Environmental Economics and Management, 67(2), 104-125.

Pigou, A. C. (1920): The Economics of Welfare, New York.

Pindyck, R. (1990). Irreversibility, uncertainty, and investment. NBER Working Paper No. 3307.

Pindyck, R. (2006). Uncertainty in Environmental Economics. NBER Working Paper, No. 12725.

Pindyck, R. (2013). Climate Change Policy: What Do the Models Tell Us?. Journal of Economic Literature. Vol. 51, pp 860-872.

Parry, I. W. H., Williams III, R. C., \& Goulder, L. H. (1999). When Can Carbon Abatement Policies Increase Welfare? The Fundamental Role of Distorted Factor Markets. Journal of Environmental Economics and Management, Vol. 37(1), 52-84.

Popp, D. (2006), R\&D Subsidies and Climate Policy: Is There a "Free Lunch"?, Climatic Change, vol. 77(3), pages 311-341

Reddy, S., G.B. Assenza, D. Assenza, F. Hasselmann (2013). Barriers and drivers to energy efficiency - A new taxonomical approach, Energy Conversion and Management, Vol. 74, Pages 403-416

Requate, T. (1998), Incentives to innovate under emission taxes and tradeable permits. European Journal of Political Economy, Vol. 14(1), pages 139-165.

Requate, T., Unold, W. (2003) Environmental policy incentives to adopt advanced abatement technology: Will the true ranking please stand up? European Economic Review, vol. 47(1), pages 125-146.

Requate, T. (2005), Timing and Commitment of Environmental Policy, Adoption of New Technology, and Repercussions on R\&D. Environmental and Resource Economics, vol. 31(2), pages 175-199

Requate, T. (2006). Environmental policy under imperfect competition. The International Yearbook of Environmental and Resource Economics 2007, 120-207.

Rodrik, D. (1988). Closing the Technology Gap: Does Trade Liberalization Really Help? NBER Working Paper Series, No. 2654.

Rohdin, P., Tholander, P., \& Solding, P. (2007). Barriers to and drivers for energy efficiency in the Swedish foundry industry. Energy Policy, Vol. 35(1), pp. 672-677.

Rozenberg, J., Vogt-Schilb, A., \& Hallegatte, S. (2014). Transition to clean capital, irreversible investment and stranded assets. World Bank Policy Research Working Papers, 6859

Salehi-Isfahani, D., Stucki, B. W., \& Deutschmann, J. (2014). The reform of energy subsidies in Iran : The role of cash transfers.

Schleifer, A. (1998). State versus Private Ownership. NBER Working Paper Series, No. 6665. 
Sutherland, R. (1991). Market Barriers to Energy-Efficiency Investments. The Energy Journal, Vol. 12 (3), pp. 15-34.

Sorrell, S., Sijm, J. (2003), Carbon Trading in the Policy Mix, Oxford Review of Economic Policy, vol. 19(3), pages $420-437$

Trianni, A., E. Cagno, P. Thollander, S. Backlund (2013). Barriers to industrial energy efficiency in foundries: a European comparison, Journal of Cleaner Production, Vol. 40, Pages 161-176,

US Dept. of Commerce. (2001). Report to the President. Global Steel Trade: Structural Problems. International Trade Administration.

Vogt-Schilb, A., \& Hallegatte, S. (2014). Marginal abatement cost curves and the optimal timing of mitigation measures. Energy Policy, 66, 645-653.

Whitley, Shelagh (2013). At cross-purposes subsidies and climate compatible investment. London: Overseas Development Institute (ODI)

World Bank. (2004). Corporate Governance Country Assessment: Moldova. Washington DC: World Bank.

World Bank. (2004). Corporate Governance Country Assessment: Romania. Washington DC: World Bank.

World Bank. (2006). Corporate Governance Country Assessment - Ukraine 2006. Washington DC: The World Bank.

World Bank. (2013). World Development Report 2014 - Risk and Opportunity: Managing Risk for Development. Washington DC: The World Bank.

World Bank. (2014). Diversified Development - Making the most of natural resources in Eurasia. Washington DC: The World Bank.

Yeo, M., Partner, Steptoe, \& Johnson. (2010). Natural Resource Subsidies. Geneva: World Trade Organization

Zhao, J. (2003), Irreversible abatement investment under cost uncertainties: tradable emission permits and emissions charges, Journal of Public Economics, Vol. 87(12), pages 2765-2789 